\title{
Duality of Structure and Culture: A Network Perspective on the Independent Cultural Scene in Zagreb and the Formation of the WHW Curatorial Collective
}

Tonković, Željka; Sekelj, Sanja

Source / Izvornik: Modern and Contemporary Artists' Networks. An Inquiry into Digital History of Art and Architecture, 2018, 166 - 192

Book chapter / Poglavlje u knjizi

Publication status / Verzija rada: Published version / Objavljena verzija rada (izdavačev PDF)

https://doi.org/10.31664/9789537875596.07

Permanent link / Trajna poveznica: https://urn.nsk.hr/urn:nbn:hr:254:930030

Rights / Prava: In copyright/Zaštićeno autorskim pravom.

Download date / Datum preuzimanja: 2023-04-26

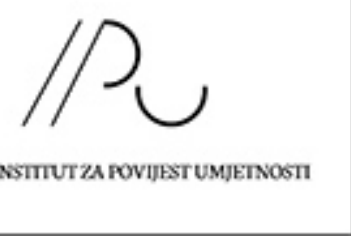

Repository / Repozitorij:

PODEST - Institute of Art History Repository

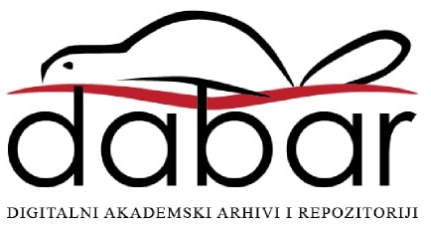




\section{INTRODUCTION}

Cultural Scene in Zagreb and the Formation of the WHW Curatorial Collective

DOI: https://doi.org/10.31664/9789537875596.07

Željka Tonković

Sanja Sekelj
The independent cultural scene is a term used for an artistic and cultural complex, whose occurrence, consolidation, and proliferation in Croatia can be traced back to the very end of the last and beginning of this millennium. Given the recency of the occurrence, it can still be regarded as an unexplored phenomenon, in which discussions regarding its basic outlines and characteristics are mostly held among its main protagonists. According to the researcher and independent scene actor, Dea Vidović the independent scene can be described as a "new cultural field", comprised mostly of non-governmental organizations, that is "specific in its agency and organization as well as its aesthetic, ideological, and political values and attitudes." 296 The author distinguishes between the two directions of independent cultural development: one that originates from the subculture, and is founded on the value principles of an archism, activism, and DIY culture as well as the heritage from social movements of the 1970s and 80s, and another one that holds the artistic value as its guiding principle, wherein the artistic and professiona context could belong to the institutiona culture. ${ }^{297}$ By emphasizing that sometimes it may be difficult to draw a line between the two directions, the author indicates that their connection is shared through the initiatives' use of a bottom-up approach, critique of socio-political context, non-profit logic, simultaneous focus on both local and

296 Dea Vidović, "Nezavisna kultura u Hrvatskoj (1990. - 2010.)," in Dizajn i nezavisna kultura, eds. Maroje Mrduljaš, and Dea Vidović (Zagreb: Savez udruga Klubtura - UPI 2M PLUS d.o.o. - KURZIV, 2010), 9.

297 Vidović, "Nezavisna kultura u Hrvatskoj (1990. - 2010)," 14-19. throughout artistic, cultural, technological, and political fields. ${ }^{298}$

Given the diversity of cultural and artistic practices and values that are created with in such a widely-defined field, in addition to the various origins of individual actors, the independent scene can be viewed as a dynamic social space comprised of close ly knit, though diverse social groups. Even though they are in a constant interrelated process of coming together and breaking apart, they form a network in which common aesthetic, social, and political values are created and shared; a space in which complex personal, social, and spatial-temporal relations are formed. The networking spaces within the independent scene can thus be viewed and interpreted a netdoms 299 - social spaces that are simultaneously based on social relations that constitute the network, and on definitions, discourses, and themes that occur within network interactions, which serve to maintain its structure.

When taking into account the attitudes and statements of the scene's protagonistsgathered through semi-structured narrative interviews - the aim of this text is to offer an interpretation of the independent scene as a social space in which structure and culture are intertwined. In other words, by using insights from the actors themselves, the aim is to outline the structure, actors and relations of the still evolving scene through 1990s, and the complex forms of communication and exchange that generated collective 'stories'.

Taking into account the aforementioned diversity of cultural and artistic practices, the

298 Ibid.

299 Harrison C. White: Identity and Control: How Social Formations Emerge (Princeton: Princeton University Press, 2008). 
focus of this text is more limited and deals with the segment of the independent scene that primarily examines visual arts, i.e. the segment that, according to Dea Vidović, could be described as being close to institutional culture in the artistic and professional sense. ${ }^{300}$ In other words, the interview analysis was conducted with a further focus on one actor in particular-the curatorial collective WHW (What, How and for Whom). Aside from the fact that the diversity of cultural and artistic practices and the various origins of individual actors is visible in the independent scene as a whole, it is also visible in the analytically extracted segment relating to institutional culture. Since the approach to the independent scene is from the perspective of its protagonists, this diversity restricts broader generalizations with regard to scene's development. As such, a comprehensive analysis of the structure, actors, and relations based on the gathered data would go beyond the framework of this text.

\section{METHODOLOGY}

Methodologically speaking, this work is based primarily on the application of a qualitative structural analysis (QSA); an innovative methodological approach in which the quantitative network analysis is linked to qualitative approaches. ${ }^{301}$ The intention

300 As is concluded by Dea Vidović, given that cultural and art practices in the independent scene almost always carry a sense of transdisciplinarity, it can often be hard to distinguish between the two developmental directions of the independent scene. This will be demonstrated in the text by referencing actors and projects that belong to the second developmental direction.

301 Andreas Herz, Luisa Peters, and Inga Truschkat, "How to Do Qualitative Structural Analysis: The Qualitative Interpretation of such an approach is to bridge the gap the qualitative and quantitative, and to develop tools that allow for interpretation of qualitative constructs with the help of concepts developed within traditional network analyses (e.g. structural holes, network centralization, homophily, and strong and weak ties). This type of methodological approach was used to analyze the gathered semi-structured narrative interviews conducted with the protagonists of the Croatian art scene in the 1990s, with the narrative data being processed using 'thematic coding'302 in order to develop and interpret analytical concepts. ${ }^{303}$

According to Herz, Peters and Truschkat, the main idea of a QSA is "to combine the analytical approach of structural analysis with analytical standards from qualitative social research". ${ }^{304}$ They argue that a "QSA goes beyond being a 'mere' combination of different analytical methods and instead integrates a structural approach within a qualitative approach". ${ }^{305}$ As stated by Kadushin, there are two main approaches in the social network analysis: the analysis of whole networks and the analysis of egocen-

of Network Maps and Narrative Interviews," Forum: Qualitative Social Research 16/1 (2015).

302 Kathy Charmaz: Constructing Grounded Theory: A Practical Guide through Qualitative Analysis (London - Thousand 0aks - New Delhi: Sage Publications, 2006)

303 In total, 29 interviews were conducted and transcribed, with a portion of the acquired data being included in the CAN_IS database. Also contributing to the conducted interviews of project ARTNET were Sanja Horvatinčić, Ivana Meštrov and Dalibor Prančević

304 Herz, Peters, and Truschkat, "How to Do Qualitative Structural Analysis," 3.

305 Ibid., 16-17. tric networks. ${ }^{306}$ In this article, an egocentric approach was applied, meaning that the main focus was on the analysis of individual relations, networks, and networking strategies of the scene's protagonists-or more specifically, the study's respondents. Following a qualitative structural analysis approach, ${ }^{307}$ a structure-focused, actor-focused, and tie-focused analysis of the interviews was applied. Structure-focused analysis includes observations re garding network density, cohesion, subgraphs (cliques), clusters, equivalence and similar structural properties of networks. An actor-focused analysis examines the positions and roles of individuals in the network; how easy is it for them to connect with other members in the network, what is their centrality like, and does an individua actor have a bridging role in the network or do they bridge structural holes? Finally, a tie-focused analysis studies the quality of relations within a network, digging into specific subgraphs; weak and strong ties between individuals in the network (in terms of emotional closeness, length of time they know each other, or type of relationship); are there multiple relations in the network, or how important is homophily. In othe words, concepts that are typical for quantitative network analyses are here used as sensitizing concepts which guide the interview analysis.

While applying qualitative structural analysis, the concentration on the curatoria collective WHW originates from the material itself: WHW is an actor that all of the study's respondents have named, either by directly describing their work and activi-

306 Charles Kadushin: Understanding Social Networks. Theories, Concepts and Findings (New York: Oxford University Press, 2012).

307 Herz, Peters, and Truschkat, "How to their ow practice or for the scene as a whole, or by using them as an example of changes that occurred at the turn of the millennium. In other words, this text does not cover the formation of the curatorial collective WHW as much as it employs their perspective in describing the scene's dynamic development through the 1990s and into the new millennium: how was the scene organized through the 1990s and in what way did the organizational models change throughout the decade and into the new millennium? In what way do the socio-political and cultura frameworks impact networking within the scene as well as the formation of individua groups? What is the curatorial collective WHW's position within the scene? Which actors are important for WHW's formation and further development? What is the relationship between the independent scene and institutional culture? And finally, in what way is the scene's structure related to its protagonists and their previously mentioned shared values?

The results gained from the qualitative structural analysis of the interviews have been expanded upon with the analysis of WHW's two collaboration networks in the initial years of their work. Through the gen erated visualizations, we consider the cooperation of the WHW collective and other organizations within the independent scene and institutional culture as well as cooperation with artists and other cultural workers realized through the organization of exhibitions and various discoursive programs. ${ }^{308}$

308 Given that the qualitative research was focused on 1990s and early 2000s, WHW's collaboration networks take into account the data from 2000 to 2006. This timespan covers the period from their first exhibition up to the time they star implementing larger European collaborative projects. 
RESULTS AND DISCUSSIONS NARRATIVE INTERVIEW ANALYSIS

STRUCTURE-FOCUSED ANALYSIS

When talking about the 1990s cultura and art scene in Croatia, it is inevitable to reference the demise of Yugoslavia and the wars that followed. Representing the most visible and radical break between the two socio-political systems, the wars were followed by a rise of nationalism and conservatism as well as stagnation in the realm of cultural production, which led the scene's actors to often describe this period as "gloomy", "traumatic" 309 or "ideologically uncomfortable and difficult". ${ }^{310}$ On one hand, the changes in the socio-political system brought a standstill to the activities of many structures/organizations, such as the Alliance of Socialist Youth and other youth organizations that served as places of experimentation and live cultural production in previous decades. Additionally, due to the imminent dangers of war, museum collections were moved to depots and were unavailable for public viewing until late 90 s. On the other hand, the lack of new strategic documents regarding cultural policies resulted in the government employing an ad hoc approach to the cultural sector-later described as neo-conservative-in which culture's only role was to symbolically represent the state. ${ }^{311}$ According to the scene's

309 Interview 4, interview by Ivana Meštrov and Željka Tonković, November 25 2015

310 Interview 11, interview by Ivana Meštrov, December 22, 2015.

311 Biserka Cvjetičanin, Vjeran Katunarić, eds., Kulturna politika Republike Hrvatske: nacionalni izvještaj (Zagreb: Ministarstvo kulture Republike Hrvatske - Institut za međunarodne odnose, 1998), 251. See also: part excluded from this process. ${ }^{312}$ This break in the continuum-labeled by one art critic and curator as a "conservative revolution"-was therefore perceived not only by the disappearance of structures and spaces, but also by the increasing inability to form relations with progressive artistic phenomena that marked the second half of the $20^{\text {th }}$ Century:

The transition from one decade into another was therefore marked with what can be perceived as analogous to the current times-frankly, it was a horrible attempt to neglect the development of both the fluxes and phenomena that have not only birthed but also defined Croatian contemporary art. In the period from the 1950s to 90 s, when art production closely followed the most important international tendencies, there was an attempt to erase it all [...] and could be called, more or less accurately, a conservative revolution. The attempt was to form what some would call a national artistic paradigm [.] ${ }^{313}$

Vidović, "Nezavisna kultura u Hrvatskoj (1990. - 2010.)," 11-13.

312 During that time, the press published art critics and artists' continuous critique of government's relentless focus on the past, naive art, and kitsch, while at the same time pointing out that the contemporary art is an indicator of Croatia belonging to Europe. The exclusion of contemporary art could also be viewed through the continuous postponement of construction of the Museum of Contemporary Art, as well as the temporary closure of several spaces, manifestations, and contemporary art festivals.

313 Interview 21, interview by Sanja Sekelj and Željka Tonković, March 6, 2017. 
There are many reasons for referencing the socio-political context and climate of the early 90 s when describing the cultural and art scene. Aside from it serving as a point of critique for many artworks and participatory actions, it also directly influenced the circumstances and means of forming networks among the scene's actors, as well as the structure itself. With regard to the latter, given that museums had to limit their activities in the early 90s and their collections were stored away in depots, many other spaces and contemporary art festivals were also temporarily put on hold. In visual arts, this was most drastically felt with the temporary closing of PM Gallery, ${ }^{314}$ which throughout the 1980s went beyond being just an exhibition space, rather it was a gathering space frequented by the protagonists of the Zagreb, Croatian, and Yugoslav scene. This space in particular was referenced by most respondents, and its closure could be regarded as a symbolic marker to the temporary cessation of artistic spaces that served as gathering spaces. Although the respondents mention certain exhibition spaces whose programs they frequented (such as Nova Gallery, Miroslav Kraljević Gallery, Zvonimir Gallery or Gallery/Museum of Contemporary Art ${ }^{315}$ ),

314 Expanded Media Gallery (PM Gallery) acted as a part of the Croatian Association of Artists (HDLU), from 1981 until autumn of 1991, when the HDLU space was occupied by the Croatian military forces at the very beginning of the war. It was reopened with the Exhibition of Food and Drinks, in May, 1994.

315 According to the interview analysis, the closure of the Gallery of Contemporary Art as a place of gathering seems to have roughly coincided with the death of its director, Davor Matičević in 1994. Although the Gallery is no longer mentioned as a relevant 'gathering space', the Museum is present in the interview analysis through not a single one of these spaces, aside from the opening reception, facilitated informal gatherings to the same extent as PM Gallery.

Consequently, unlike the previous decades wherein progressive art currents could be linked to specific exhibition spaces, in the 1990s most of the gatherings took place in informal spaces such as coffee shops, bars, and clubs as well as certain public spaces or offices of NGOs and activist initiatives where relationships were built and projects initiated:

What is essentially left? [after transition, with the disappearance of all former structures] In my opinion, the only thing left were these informal elements of gathering. Along the lines of, two of us get together in a bar and then figure something out. Most of these projects, from Arkzin to Attack, and even WHW, were formed in random bars; Arkzin was formed sometime in autumn on some terrace in Tkalčićeva Street, the first WHW exhibition project was conceived in BP Club, etc. ${ }^{316}$

On one hand, the consequence of exhibition spaces ceasing to serve as gathering spaces was the proliferation of artistic events in alternative exhibition spaces. The respondents of the study point to several crucial events such as the exhibition held at the Flower Square's abandoned Old Vjesnik printing house, marking Earth Day. Another one took place in a tunnel under Zagreb's Grič, originally designed as a shelter during Second Word War, followed by exhibitions held at the abandoned toy factory

the activities of individual curators, such as Nada Beroš, Tihomir Milovac, Želimir Koščević, and Leonida Kovač. 316 Interview 17, interview by Željka Tonković, March 17, 2016. complex Biserka as well as many individual art interventions in public space. ${ }^{317}$ On the other hand, the constant lack of resources defined a whole generation of young artists art critics, and other cultural workers who, by seizing these spaces as symbolic representations of their own positions as well as physical spaces for work, defined one of the leitmotifs of the cultural and art scene in the 1990s and early 2000s. ${ }^{318}$

Moreover, this lack of gathering spaces was most likely the reason why the cultural and artistic scene in the 1990s was fractured and informally organized around narrow social circles. One of the study's respondents, a new media artist, explains the interrelation of private contacts and formal networks as follows:

It is one and the same. Private network is the network. Other forms of network simply did not exist in Croatia in the 90s. It was exclusively private networking, which predominantly

317 The installation exhibition observing the Earth Day was organized by artists Magdalena Pederin and Snježana Karamarko, as a part of the Life Quality Improvement Organization activities, and took place from April 18th through May 1st 1994. The exhibition, In the Tunnel, was also held on Earth Day, from end of April to beginning of May in 1995, and was organized by artists Magdalena Pederin and Ivan Marušić Klif, while side events, concerts and performances, were organized by Boris Bakal. The exhibition, Toy Factory, was also organized by Magdalena Pederin as a part of the ATTACK! program, taking place from May 23rd to June 12th 1998. 318 For more see, for example: Vidović, "Nezavisna kultura u Hrvatskoj (1990. 2010.)," 32-33. See also: Dea Vidović, "Taktičke prakse u pristupima lokalnin kulturnim politikama u Zagrebu," Život umjetnosti 86 (2010): 22-35. took place in bars. There are no gathering spaces, no mailing lists, and no networks. Well, there are two functioning networks; as mentioned, one was Soros, and the other was Culturelink, whose international activities were concerned with other issues. ${ }^{319}$

The same artist would later go on to say that true networking only began in Croatia at the turn of the millennium:

There was a turning point in the 2000s with the formation of WHW and their first exhibition. For the first time, the networking expanded to a second group around Mama, as well as a third group around CDU, with Sergej and Frakcija. These three groups really hit it off, and Croats finally understood what networking meant. In the 90 s this simply wasn't the case. [...] The conscious networking only came about in the 2000s when these three groups came together and started working on POLICY_FORUM. ${ }^{320}$

At the turn of the millennium, the organizational logic of cultural actors changedone year after the 2000 elections that brought a change in government, there was a restructuring of laws governing the formation of NGOs, making the registration process easier and providing more opportunities for accessing public financing for the arts. With the proliferation of numerous cultural NGOs, there came a tactical networking effort of local and national ac tors through the newly formed platform Clubture and Zagreb - European Cultura

319 Interview 2, interview by Ivana Meštrov and Željka Tonković, November 24 , 2015.

320 Ibid. 


\section{INVISIBLEZAGREB}

Read • 3LHD • STEALTH group

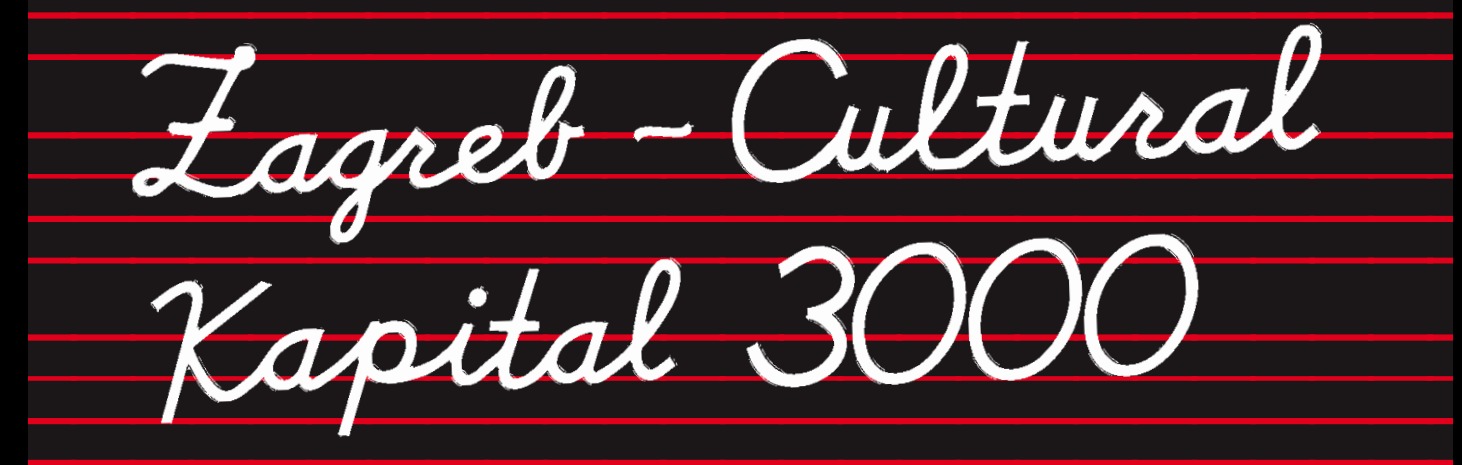

CENTAR ZA DRAMSKU UMJETNOST MULTIMEDIJALNI INSTITUT PLATFORMA 9,81 : ŠTO, KAKO I ZA KOGA [WHW]
Kapital 3000.321 Their shared purpose was primarily to nurture cooperation through program exchanges and development, and share resources with the aim of further strengthening the scene at large. At the same time, in order to reinforce their position, the platforms furthered their advocacy efforts through closely following cultural policies and actively participating in the changes and implementations. Due to sudden expansion, the rhizomatic spread of organizations, and the need for networking, many of the study's respondents identified this structural change in the cultural field as the moment that allowed for the development of the scene to run parallel to institutional culture.

For respondents that participated in the activities of the Zagreb - European Cultural Kapital 3000 platform, the formation of the independent scene at the turn of the millennium can be seen through a prism of "self-institutionalization" and "self-organization"-given that the needs of new actors surpass the levels of individual initiatives and actions and create their own organizational forms. Reflecting on the difference in networking and collaborative practices of the 1990s and early 2000s, one of the respondents pointed out that in the 90s, "there was no model". Rather, the socialization and one-time initiatives were seen more "as a lifestyle", lacking any "real structural relationships". In contrast, the logic behind networking in the Cultural Kapital platform was quite different:

321 For more info about Clubture platform, see: "Clubture." Accessed August 14, 2018. http://www.clubture.org/ For more info about platform Zagreb European Cultural Kapital 3000, see: Multimedia Institute, "Zagreb - European Cultural Kapital 3000." Accessed August

14, 2018. www.mi2.hr/hr/suradnje/

zagreb-kulturni-kapital-evrope-3000/
We were following a different kind of logic, one of self-organization. (...) In the 2000s, efforts were made to connect all of these cultural NGOs with the aim of strengthening and providing a lasting framework for cultural activities. One of the guiding principles was for networks to serve as a foundation for a new cultural center, a new type of institution for contemporary cultural practices. I believe that is the key difference between the alternative scene of the 80 s and the independent scene that originated in the 90 s, because the scene that took hold in the 2000 did not accept the label of alterna tive culture, unlike the one formed in the 80 s. ${ }^{322}$

Still, one of the key issues that persisted in the early 2000s was the lack of working spaces (and sufficient resources for cultura production in general) that would enable organizations to gain greater visibility, thus driving the scene to focus on collective ac tion and cooperation, as demonstrated in the aforementioned platforms. According to one of the members of the Multimedia Institute, solidarity and resource sharing came as the result of a joint effort by these organizations in offering context for critical contemporary art practices, while the idea of 'gathering' and collective action was the result of a belief that "the basic cultural infrastructure is not defined by buildings and operational costs, but by cooperation". ${ }^{323}$

The study's respondents often linked the propulsion and sudden expansion of the scene from the 2000s onward with the es-

322 Interview 18, interview by Sanja Sekelj and Željka Tonković, December 6 , 2016.

323 Interview 12, interview by Ivana Meštrov, January 13, 2016 
tablishment of the WHW curatorial collective, namely, the first exhibition organized by the independent curators Ana Dević, Nataša llić, and Sabina Sabolović, who were later joined by Ivet Curlin. The exhibition took place at the Croatian Association of Artists in 2000, under the title What, How, and for Whom? On the Occasion of 152 Years of Communist Manifesto, which would later become the name of the collective and NGO. ${ }^{324}$ Thanks to the members of the collective, the inspiration for and the execution of the exhibition are well known: the initiative came from the magazine, Arkzin and its editor in chief, Dejan Kršić, with the aim of increasing visibility of Arkzin's 1998 reissue of the Communist Manifesto, with a foreword by Slavoj Žižek. ${ }^{325}$ Initially, the planned 1998 exhibition was supposed to include several

324 The exhibition took place at the Meštrović Pavillion in Zagreb, June 16th - July 10th 2000, and was organized in collaboration of independent curators (An Dević, Nataša Ilić and Sabina Sabolović), Arkzin, Multimedia Institute, and Croatian Association of Artists. The list of exhibiting artists can be found at WHW website: WHW, "What, How and for Whom: On the 0ccasion of 152nd anniversary of the Communist Manifesto." Accessed July 25, 2018. http://www.whw.hr/izlozbe/2000_izlozbal.html >

325 See, for example: Una Bauer, "Crvene niti kontinuiteta i kolaboracije - intervj s kustoskim kolektivom WHW." Kulturpunkt, March 9, 2010. Accessed July 25, 2018. https://www.kulturpunkt.hr/content/crvene-niti-kontinuiteta-i-kolaboracije-0. Dea Vidović, "Život s WHW-om - intervju s Dejanom Kršićem." Kulturpunkt, August 16, 2010. Accessed July 25, 2018. https:// www. kulturpunkt.hr/content $/ \%$ C5\%BEivots-whw-om. Sven Spieker, "Interview with WHW Collective." ARTMargins, July 5, 2011. Accessed July 25, 2018. http://www.artmargins.com/index.php/5-interviews/635-interview-with-whw-collective-zagreb. young Croatian artists, but ended up hapening in 2000 with almost 50 artists from across Europe, predominantly ex-Yugoslavia and former Eastern Bloc countries. In conjunction with the exhibition, and organized in collaboration with the Multimedia Institute, there was an extensive program of lectures, discussions, and projections that included curators from Serbia, Slovenia, and Albania, as well as Hito Steyerl, Frederic Jameson, and Richard Barbrook.

According to respondents, the curatorial collective WHW held one of the central roles within the independent scene structure, and their contribution to the tactical organization of the scene was often emphasized. The collective's curators belong to a younger generation of cultural actors, whose early work critically examined and reflected upon the socio-political and cultural climate that affected them throughout the 1990s. In their words, the project can also be interpreted in the spirit of generational rights in establishing their own attitudes towards the past as well as the need for the restoration of continuum with regard to the artistic phenomena of the socialist period. ${ }^{326}$

Alongside the Multimedia Institute, the Centre for Drama Arts, and Platform 9.81, the WHW curatorial collective was also one of the core members of the Zagreb - European Cultural Kapital 3000 platform, and one of the first members of the Clubture platform. Aside from participating in collaborative efforts of the scene, this element of collectivity is present in WHW's work in general. On one hand, WHW is a collective, curatorial identity that jointly signs exhibitions, texts, and other programs, in addition to sharing work obligations. One of the members correlates the subject of collective work with the pragmatism of shared workloads but also with the increased visibility in the

326 Bauer, "Crvene niti kontinuiteta i kolaboracije." public landscape that originates from the collective platform, emphasizing that collective work is

[...] both a necessity and a matter of choice, because choices carr certain consequences - the way you organize your time, your life, and ultimately, how you organize certain choices in life. (... $)^{327}$

On the other hand, the elements of collectivity in WHW's work can be recognized in their lasting quest for establishing a symbolic space for dialogue, networking and collaboration of various actors. This was already present in the organizational effort leading to the Communist Manifesto exhibition, first through WHW's collaboration with Arkzin, the Multimedia Institute, and the Croatian Association of Artists, and second, with the subsequent integration of artists, curators, and art historians through various participatory and discoursive formats. One of WHW's members goes on to say that in the 1990s "a great isolation and complete lack of communication on any level was a constant with regard to cultural produc tion", thus making collaboration "a centra issue of WHW's first exhibition, and in fact of all of our projects moving forward." ${ }^{228}$

\section{ACTOR FOCUSED ANALYSIS}

When asked about actors whose roles were crucial in the forming of networks in the 1990s scene, the respondents predominantly reference their own project collaborators or artists whose practice was interesting and/or formative for their own

327 Interview 20, interview by Sanja Sekelj, December 8, 2016.

328 Interview 16, interview by Sanja Horvatinčić and Željka Tonković, March 29, 2016 work, or whose segments stood out from the wik of art production at the time. Almost every art historian, curator, and artist who was active in the 90s art scene is listed in the full interview; institutional art protagonists such as Museum of Contemporary Art curators, employees of the Soros Center for Contemporary Art, artists connected to the PM Gallery during the 1980s, and even younger artists who were fresh out of the Zagreb Art Academy.

Given the nature and diversity of the in terview responses, there are a few people that can be singled out as important or formative for the scene at large, due to either their frequent referencing or emphasis of their role. For example, Slaven Tolj's significance was emphasized in most of the interviews with regard to both his art practice and event organization at the Ar Workshop Lazareti in Dubrovnik, as wer contributions from the mid-generation artists, Mladen Stilinović and Sanja Iveković Even though the roles of the latter two are also referenced with regard to the relevancy of their artistic practices, younger genera tion art historians and artists predominantly list them in the context of sourcing and in formation sharing, an alternative education of sorts that greatly influenced their formation. This role was also highlighted by the members of the WHW collective, who refer to both the more formalized method of education such as Sanja Iveković's workshops, executed through her NGO Elektra - Women's Art Center, and also more informal moments of gathering and information proliferation:

[...] due to a true lack of resources, people were referred to one another. You couldn't really travel much, and there wasn't much to see, but there was a nice practice out of which perhaps came this spark of collectivity through WHW. I remember [the two 
of us from the collective] exchanging books and catalogues every time somebody would go traveling abroad; the ritual of catalogue ex changes, of unearthing the catalogues together, but I also have to admit that both Stilinović and Sanja were very interested in lending books and giving oral deliberations in order to open up new worlds for those who recently graduated or were stil students and simply didn't have a chance to discover these worlds. ${ }^{329}$

Aside from the role of the mid-generation artists, the members of the WHW collective also underscore the relevancy of activist initiatives and practices for their own formative state. After listing numerous young artists whose work she followed, one of the members of the collective concludes:

I was perhaps gravitating more to circles around ATTACK! and Arkzin that were not necessarily connected to the arts. If I were to draw a line, I would say that I mostly followed the activities of ATTACK! and Arkzin. During and shortly after university studies, I also followed Sanja lveković who worked on several projects through Elektra where she held seminars that involved young students and art historians. ${ }^{330}$

Another member of the collective points out how, in the 1990s art field, there was a lack of cooperation and communication a opposed to the 2000s, and interprets the importance of the activist scene in term of its organization, versatility, and sense of togetherness, while at the same time, she interprets the general need for cooperation sendents, the importance of the an i-war, pacifist, and the associated anarchist and feminist initiatives played an im portant role in cultural and art fields in the 90 s and 2000s. Even though the umbrella organization of the peace movement, th Croatian Anti-war Campaign, gets rare ly mentioned, ${ }^{332}$ the connection between the activism of the 1990s and that of the emerging art scene can be interpreted both through the participation of some artists in the organization's activities, and through their support for certain art events. For example, the aforementioned relevant art projects, such as the one held at the Old Vjesnik printing house to mark Earth Day in 1994 came together with the help of the Life Quality Improvement Society, one of the NGOs that founded the Anti-war Campaign. They furnished the participants with working spaces and assisted with administrational and organizational tasks. Howev er, the influence of the Anti-war Campaign in forming the independent scene can be primarily observed through their Arkzi magazine, whose first issue came out as a fanzine in 1991, as well as through the influence of ATTACK! - Autonomous Cultura Factory, an NGO founded in 1997.333

331 Interview 16

332 For more on Croatian Anti-war Campaign, see: Vesna Janković, Nikola Mokrović, eds., Antiratna kampanja 1991. 2011. Neispričana povijest (Zagreb: Documenta - Centar za suočavanje s prošlošću - Antiratna kampanja, 2011) Paul Stubbs, "Networks, Organisations, Movements: Narratives and Shapes of Three Waves of Activism in Croatia," Polemos 15 (2012): 11-32

333 For basic info about Arkzin, see Tomislav Medak, Petar Milat, eds. Prospects of Arkzin / Izgledi Arkzina
(Zagreb: Arkzin - Multimedijalni institut, 2013); For more about ATTACK!, see: 
The awareness of the greater socio-political context and openness to diverse forms of civil initiatives and artistic expressions were characteristic of both the magazine and the NGO. The contents of Arkzin's editorials ranged from critiques of the state apparatus, to reports of peace initiatives, minority rights, ecological catastrophes and initiatives, macrobiotics, current rave parties, as well as theoretical texts by Slavoj Žižek and Terry Eagleton, among others. The magazine also covered film, concerts, theater and dance performances, fanzines and exhibitions, as well as new media events from across Europe and America. Similarly, ATTACK! organized events on topics of ecology, human rights, and political accountability, and provided an organizational framework and means to numerous theater, music, and film groups and alternative art events. According to Vesna Janković, ${ }^{334}$ the focus on versatility of artistic expressions, their interconnectivity and a shared perception of art and culture as social and political processes created a "form of bastardy, hybridity [that was] a novelty on the civil scene". 335 Due to this openness, the respondents simultaneously perceive Arkzin and ATTACK! as being both important actors on the scene and important places of gathering. They emphasized that "at the time, Arkzin served as a recognition mechanism of sorts", ${ }^{336}$ or was called, alongside ATTACK!, WHW and the Multimedia Institute, a "spiritual gener-

Naša priča: 15 godina ATTACK!-a (Zagreb: Autonomni kulturni centar, 2013).

334 Vesna Janković was editor-in-chief of Arkzin from 1992 to 1997, as well as one of the founding members of ATTACK! 335 Vesna Janković, Marko Strpić, "Mi gradimo Attack, Attack gradi nas!," in Naša priča: 15 godina ATTACK!-a, 25.

336 Interview 1, interview by Ivana Meštrov and Željka Tonković, November 3, 2015. ator" of the scene..$^{337}$ One of the members of the WHW collective recognizes ATTACK! as an informal space with a potential for gathering people, while the atmosphere around Arkzin - who initiated the first WHW exhibition-proved crucial in the strengthening of own practice, adding

Arkzin [...] was extremely important. It was important to me as a politically thoughtful being, so it was great that our project was an idea born out of Arkzin. [...] I believe Arkzin does incredibly important work. [...] Arkzin was truly a political, pop cultural magazine. I think it was very important also because it provided translations, being a pioneer in some theoretical translations, publishing articles on international art practices that were completely absent from our mainstream. And it wasn't moving away from theory, but rather insisted on it-trying to dig deeper into more complex and problematic approaches in places of trauma. ${ }^{338}$

Even though Arkzin and ATTACK! served as physical gathering spaces of various actors, the respondents most commonly treat the magazine and NGO, as well as other aforementioned organizations such as WHW or the Multimedia Institute, as scene's actors. In other words, the change in organizational logic at the turn of the millennium is also reflected in the perception of the key actors who generate the scene. Moreover, they are not individuals but rather NGOs who, from the 2000s onward, not only form the structure, but are also the scene's most important bridging actors and concentrators. The respondents also relate the founding of the WHW curatorial collective at the turn of

337 Interview 11.

338 Interview 16. the millennium to a point from which the Croatian art scene is organizationally run by curatorial collectives and independent curators. Interestingly, the projects that were identified by the respondents as being important for the 90 s art scene were, for the most part, created and organized by artists. The artists and organizers of these alternative events in the 90 s would go on to describe their involvement as a need for self-expression, for entering the public sphere and opening up dialogue-a need to simply do, in spite of slim resources. At the same time, they qualify the formation of curatorial collectives at the turn of the millennium as a point in time from which they could concentrate more thoroughly on their own artistic practices, since "it seemed needless for us to do work that is not in fact our job". 339

\section{TIE FOCUSED ANALYSIS}

In continuation of the aforementioned assertion regarding the lack of a structural approach to collaborative practices in the 90 s, the interview analysis identified a few themes according to the type and quality of relations created in the art scene. Given the previously described socio-politica context and climate of the 90s, the lack of structures and material resources made collaboration the foundational capital of the emerging scene. One of the WHW members asserts that "people were referred to one another due to lack of resources"; 340 another respondent states that during the 90 s, there was no strategy but an "impulse to collaborate"; ${ }^{341}$ while a younger generation artist identifies the need for unity throughout the 90s:

I was under the impression that ou gatherings were not of any specia

339 Interview 25

340 Interview 20 nature. I mean, there were very few artists that did stuff and so we kept together. There was no room to criticize each other. We were surrounded by things that were threatening our livelihoods [...] and so we simply stuck together during this period. ${ }^{342}$

Overall, the interviews have indicated several different types of connections between actors, which for the most part seem difficult to differentiate, thus pointing to the fact that art scene protagonists nurtured multiple relations. The study's respondent often point out the importance of comradeship in accomplishing certain projects, with an emphasis on friendships and networks within their own generation. This is, according to one WHW member, "something that has its own rhythm, enthusiasm, and type of fluidity", ${ }^{343}$ while at certain points this element of friendship mixes with the element of "recognition" based on shared aesthetica and ideological values, ultimately making it impossible to differentiate between the two. For example, when speaking about the art project The Order of Bank and Money Worshipers ${ }^{344}$ one new media artist states:

\section{Interview 25.}

343 Interview 20.

344 The Order of Bank and Money Worshipers was an art project that took place from autumn of 1994 till spring of 1995, and was made up of interdisciplinary group of artists, dramaturges, architects and musicians. The activities of the group were comprised of unannounced micro-performances taking place in banks across Zagreb, raising the issues of changes in the socio-political context through emphasizing the rituality of the space. See for example: Katarina Pejović, "Bakal, Boris: navigator izmještanja i diskontinuiteta - portret multimedijalnog umjetnika, Up \& Underground 7/8 (2004), 26. 
There is this one art group-they even called me, and now I'm sorry I didn't join - the The Order of Bank and Money Worshipers. This was a completely bottom-up initiative. [...] It was one of the better art projects in the 90s. The Order of Bank and Money Worshipers [...] was an informal mix, along the lines of we all know each other, we're friends, this is how it goes. There was no institution at all. It was all recognition-based. It was all about recognizing each other on the street. Today, you have these residencies, and that's something new. It didn't exist back then. We were working off of a scent-somebody articulates an idea, another one builds upon it. ${ }^{345}$

The friendship element is especially pronounced in the early onset of professional engagements of the new generation artists and art historians. Though, when analyzing the interviews as a whole, it can be concluded that the element of "recognition" tips the scale and is determined by project accomplishments, shared acquaintances, frequenting the same informal gathering spaces, or even participating in the events that become collective spaces of resistance to the dominant socio-political or cultural climate. For instance, one of the WHW members speaks of "scandalously traumatic spaces that generated a certain kind of a scene" 346 in the 90 s, such as the devastation of the Flower Square in Zagreb or the installment of a new director a the Museum of Contemporary Art in 1998. Moreover, when talking about networking related to the platform Cultural Kapital, another respondent gives a direct advan-

345 Interview 2.

346 Interview 16 ather than friendship, saying:

Neither I nor any one of us were in some kind of special friendship relations [...] these collaborations were made following the logic of recognition, not only through the work we do but also, in my opinion, through a shared work ethic. ${ }^{347}$

The social circles in the independent scene were therefore founded on mechanisms of status and value-based homophily as well as transitivity. Regarding the former, the actors shared a social status that implied the claiming of spaces outside institutional culture as well as sharing aesthetical and ideological views based on left-leaning political ideas, the critique of the socio-political context, as well as a tendency toward art experimentation. While with respect to transitivity, most of the actors with similar affinities connected rather quickly to one another due to the relatively small size of the scene. ${ }^{348}$ Relations established through these mechanisms carried a sense of permanence and often implied long-lasting collaborations in which the professional and friendship relations are intertwined. At the same time, their foundation in value-based homophily created a network that was homogenous in its basic ideological values, while at the same time, heterogeneous in discipline through the inclusion of interdisciplinary groups of artists, activists and humanities experts.

In contrast to the above described spontaneous generation of sociability, the rela347 Interview 18.

348 The formation of informal social circles based on status and value homophily is one of the typical signifiers in the cultural and art fields. See: Kadushin, Understanding Social Networks. tions of some actors were also established through more formal channels, such as participation in international art and communication networks, which were a novel ty in the arena of European cultural policy of the 90 s. ${ }^{349}$ The majority of respondents identified Zagreb's Soros Center for Contemporary Art (SCCA) as the key interme diary for establishing art relations with both the international and domestic actors. In addition to providing financial support fo certain artistic and curatorial projects, the Center acted as an information hub for international art happenings and connected domestic artists and curators with colleagues from abroad. Its role was also emphasized by the WHW members, citing the Center's support for their first international exchanges and residencies. One of the members also highlights meeting her WHW colleague due to a Soros grant, followed by the artist Sanja Iveković with whom the collective established a perma nent collaboration. Due to the difficultie in establishing communications in the 90 s, the grant also helped in connecting and collaborating with colleagues from Slove nia, Bosnia and Herzegovina, and Serbia, making it an important part of their work even from their first exhibition.

Alongside the SCCA, the international connections were also established thanks to a greater presence of new communication technologies. However, even though these kinds of gatherings or interaction imply a sense of 'anonymity' among the participants, the conducted study suggest that the participation in large international networks was also personalized, and is perceived by the respondents through forming relations based on similar aesthetical and ideological affinities. In this sense, the establishment of relations among

349 Cf. Vidović, "Razvoj hrvatske nezavisne scene (1990. - 2002.)," 14 artists and curators could be inilarly to the domestic art scene processes, resulting in several very strong connections with international curators and artists. From the perspective of the independent scene at large, some relation between domestic and international actors can therefore be described as weak and strong at the same time. They can simultaneously imply a long-lasting and close collaboration with a specific actor, while through short-term contact, the rest of the independent scene receives new information that can, to a greater or lesser extent, influence the further development of individual artists or even the scene as a whole. The first exhibition of the WHW curatoria collective included a large number of international artists precisely due to the earlie established international networks. Thei participation brought new values, context and perspectives to the local scene, and in turn, domestic art production was given a broader context and greater international visibility. Given the ambitiousness of WHW's initial projects and other curatoria collectives of the time, such as Kontejne and BLOK, their high levels of organization and efforts to connect domestic artist with international curators and collaborators, the respondents draw a distinction between institutional and independen culture. Namely, pointing to openness and flexibility of the independent scene versus institutional sluggishness, and defining the turn of millennium as the moment when the independent curatorial initiatives took over the production and promotion of contemporary art. In other words, according to one mid-generation curator, after the year 2000, "when WHW emerged, that whole generation carried the independen scene $[. .$.$] contemporary art was carried by$ the independent scene". ${ }^{350}$

350 Interview 1 


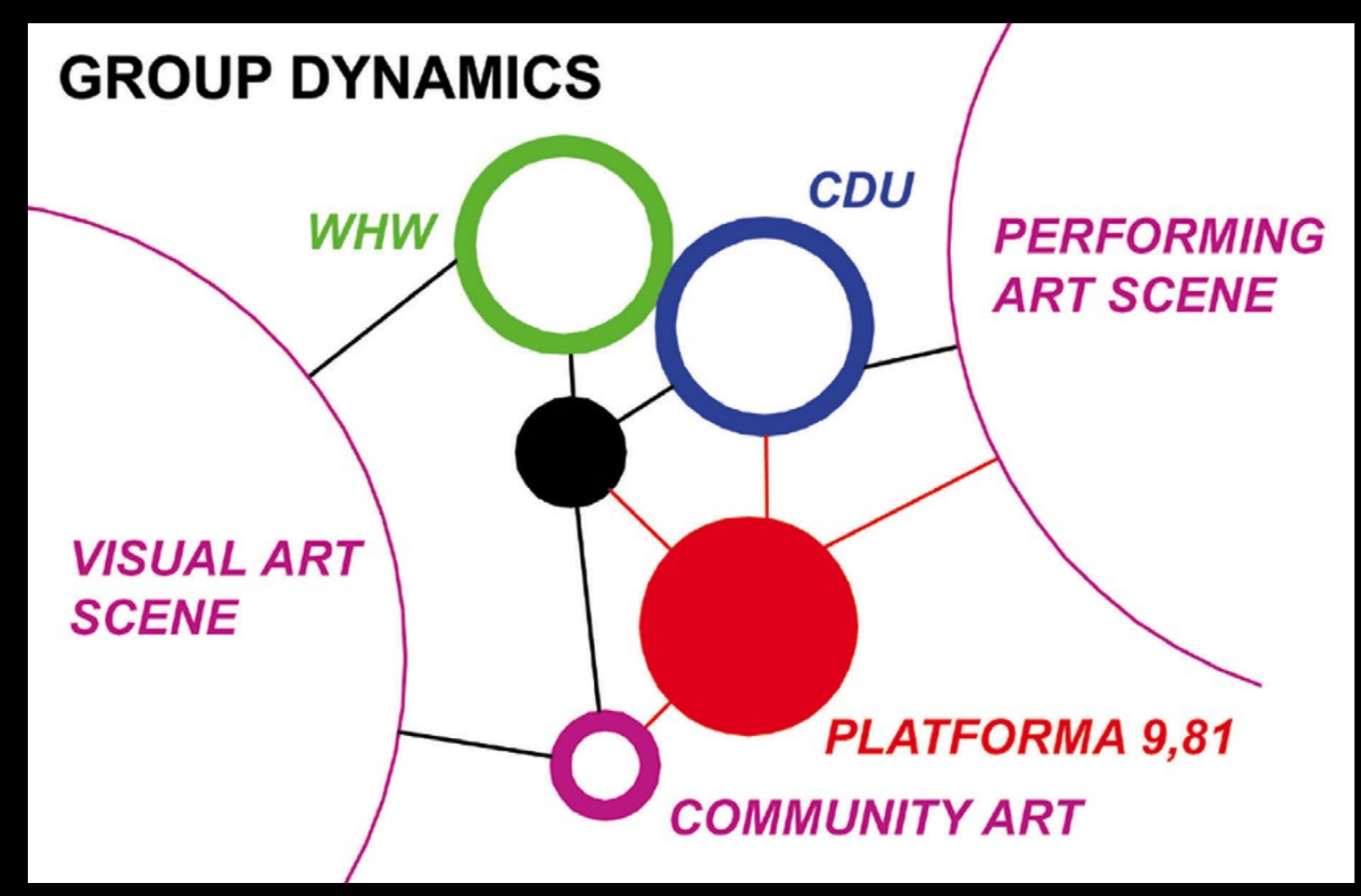

III. 4
However, the relations between the independent scene and institutional culture cannot be viewed through a simple dichotomy, and are rather much more complex. And although the majority of respondent assessed the relations between these two sectors as virtually non-existent or existing in a "state of mutual indifference", ${ }^{351}$ severa respondents have recognized the efforts of a few institutional workers in bridging the gap between the two sectors by supporting the realization of art and curatorial projects produced by the younger generation.

One of the important mediators in the case of WHW's founding was Nevena Tudor, the director of Croatian Association of Artists (HDLU) in the early 2000s. She was identified, not only by WHW members, but also by many younger generation respondents as the key enabler in the realization of their ambitious projects by providing them exhibition spaces and ensuring greater visibility through HDLU's program. ${ }^{352}$ The WHW members highlight her openness toward the younger generation of artists and curators fresh out of university, and also provide a specific view of the relations between the independent scene and institutional culture at large: by mediating between the two sectors, some institutional workers enabled the "reclaiming of traditional institutions", or at

351 Interview 12

352 Her role in supporting the independent scene was previously highlighted by the critic Marko Golub, primarily for opening up spaces for inclusion of independent scene actors when organizing the 25th and 26th Youth Salon, which aided the further consolidation of the scene by gathering of all current and future actors in one place. See: Srdan Sandić, "Kritičar kao dionik, zagovarač i medijator - intervju s Markom Golubom." Vizkultura, March 9, 2016. Accessed

July 25, 2018. https://vizkultura.hr/ kriticar-kao-dionik-zagovarac-i-medijator/. east "opened new possibilities for particand dialogue" 353 Additionally, by providing greater visibility for independen projects, which delivered a more poten socio-political critique to the curatoria concept, WHW members also saw these individuals as crucial to the development of the art scene at large:

When we first started working, we didn't want to create a project that would stay at the same level as Arkzin and remain outside of institutional culture. Our initial intention was to find ways of infiltrating the institutional space with our socio-political critique, and that was an important project goal. ${ }^{354}$

In that sense, the problems were deep-rooted, and it was impossible to expect institutions to offer a more complex insight into social realities. Yet, precisely because of that, it was important that the projects such a Communist Manifesto take place within an institution, as was the cas with Broadcasting. The institution are crucial, but not as entities, rather as people within the institutions. ${ }^{355}$

ANALYSIS AND VISUALIZATION OF COLLABORATIVE NETWORKS OF THE WHW CURATORIAL COLLECTIVE

Given the aforementioned assertions that collaboration is the main capital of the emerging scene, and that after 2000, the role of key actors in the network is inhabited by newly formed NGOs, the collaboration

353 Interview 17, interview by Ivana Meštrov and Željka Tonković, March 29, 2016.

354 Interview 16

355 Interview 20 


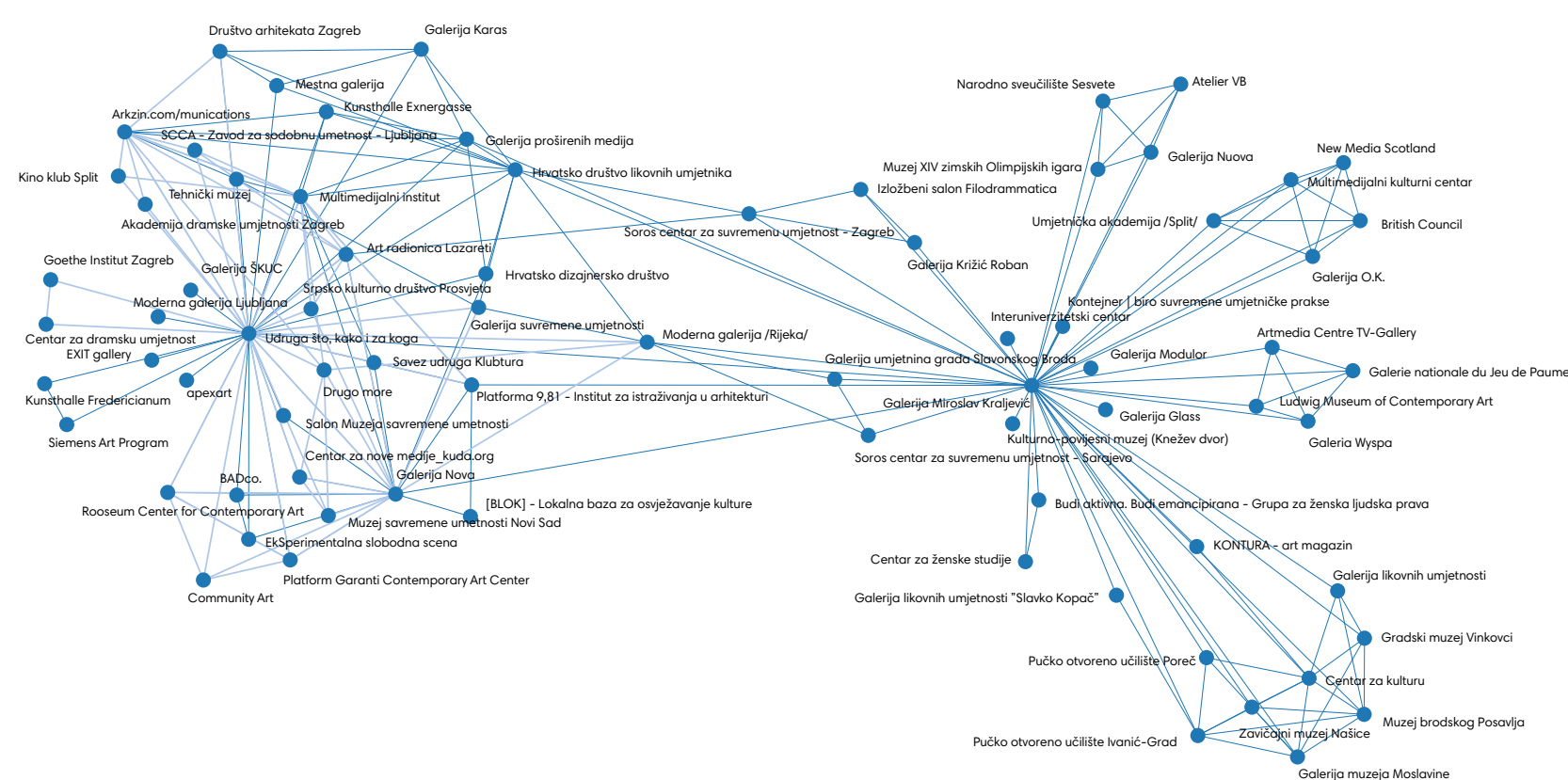

Fig. 1

Institutional collaboration of the WHW curatorial collective between 2000-2006 network of the WHW collective with other organizations (2000 to 2006) offers a glimpse into their initial strategic partnerships (Fig. 1). The relations between actors/ organizations in this one-mode network represent the organizational collaboration of art exhibitions and discoursive events, with consideration of both complex forms of collaboration through program production as well as smaller contributions through the lending of spaces or including authored projects in the yearly programs of other organizations.

The visualization primarily offers an insight into the intensive network growth of WHW, realized within only six years of their work. In the first two years, they established collaborations with cultural institutions in Croatia (HDLU, Technical Museum) and Slovenia (ŠKUC Gallery, Mestna Gallery), as well as with NGOs (Multimedia Institute, Arkzin. com/munications). The collaborations with the Multimedia Institute and Arkzin can be considered as strong ties that last to this day, and the institutional relations could be either interpreted as a form of 'infiltration' or a search for an adequate space to present their work, while the Slovenian institutional collaborations can be seen as fulfilling a need to reestablish connections with the centers of ex-Yugoslavia.

One of the WHW exhibitions, A Small Country for a Big Vacation, that took place in ŠKUC Gallery, ${ }^{356}$ was realized through the Middle-South-East Projects, initiated during Ljubljana's Manifesta 3 in 2000. The goal of the project was to intensify the exchange of programs and insights of actors from Lju bljana, Zagreb, Budapest, Sarajevo, Graz, and Bologna. ${ }^{357}$ In addition to ŠKUC Gallery

356 The exhibition curators were Nataša Ilić and Ana Dević, and it took place at the ŠKUC Gallery, from September 14th October 8th 2000. and SCCA Sarajevo, one of the WHW memspecifically highlights this project and the role of <rotor> Gallery from Graz, as an important meeting place for artists and curators from the ex-Yugoslavian countries. ${ }^{35}$ The collaboration with Mestna Gallery in Ljubljana was realized in 2002 with the exhibition Start, with the goal of showcasing young artists from Croatia and Slovenia, and reconnecting the two artistic milieus. After 2003, there was an increase in the quantity of programs and intensification of organizational networking, following WHW's appointment to a new curatorial role in $\mathrm{Za}$ greb's Nova Gallery. With the continuation of close collaborations with the Multimedia Institute and Arkzin, primarily seen through collaborations with designer Dejan Kršic (sometimes listed as the $5^{\text {th }}$ member of the collective), most of the collaborations leading up to 2006 were established with NGOs.

Local collaborative efforts were realized through the platform, Zagreb - European Cultural Kapital 3000 (Multimedia Institute Platform 9.81, BLOK, Shadow Casters, Community Art, Centre for Drama Arts), and included productions of thematic programs that dealt with issues of group and collective work, relations of independent scene and institutional culture, public accessibility and democratization of culture, or even critical analysis of the wider social contex of 'normalization' that enabled the growt of the independent scene. In other words, the programs dealt with specific issues tha were the focus of Cultural Kapital platform's advocacy activities.

In conjunction with local networking, collaborations were established on a nationa level through the Clubture platform. Th strengthening of ties with the Art Workshop

ŠKUC Gallery, "Why MSE-projects?" Accessed October 4, 2018. http://www.galerijaskuc. si/v2/why-mse-projects/.

358 Interview 20. 


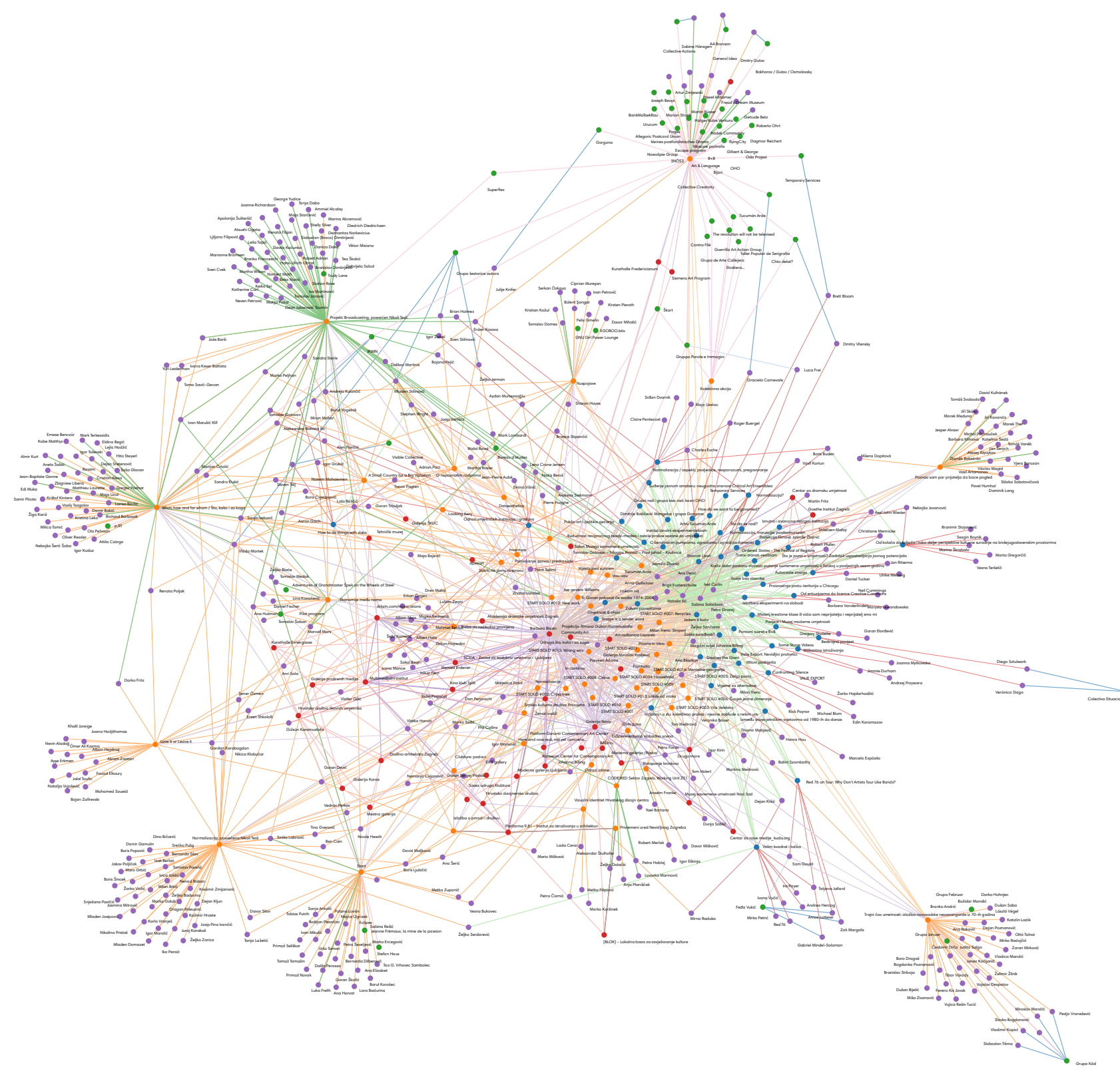

Fig. 2

Collaborative network of the WHW curatorial collective 2000-2006
Lazareti in Dubrovnik and Drugo More in Rijeka was of great importance, which brought discoursive program exchanges with lectures by visiting international art ists, art groups, and curators across multiple locations in the country (e.g. Charles Esche, Barbara Vanderlinden, Gregory Scholette). It is interesting to note that the programs realized through these two platforms enabled WHW to further develop their international collaborative efforts namely with the Center for Contemporar Art Rooseum in Malmö, led by Charles Es che, Platform Garanti from Istanbul, led by Vasif Kortun, as well as the New Media Center kuda.org from Novi Sad, a collaboration that continues beyond 2006 with the project, Political Practices in Post-Yu goslavian Art, ${ }^{359}$ in an effort to strengthen ties with NGOs in Serbia.

The situation becomes much more complex with the inclusion of all realized programs in WHW's collaborative network. Alongside institutions and NGOs, the constructed tota collaborative network (Fig. 2) also include all exhibitions and discoursive program that were either organized or co-organized by the WHW curatorial collective, as well as all individuals and art groups that participated in the programs as either organiz ers or participants. The result is a complex multimodal network with a central position made of four members of the WHW curatorial collective, who, from 2000 to 2006 organized 56 exhibitions and 51 discoursive events, and established relations with 400 individuals and 50 art groups.

Larger international exhibition projects are clearly visible at the edges of the vis ualization and include exhibitions realized

359 Alongside WHW, the project partners were Prelom Collective from Belgrade, kuda.org from Novi Sad, and pro.ba/SCCA from Sarajevo, and it lasted from 2006 until 2010 's curatorial concepts or exthrous visiting curators in Nova Gallery, where WHW members acted as event organizers and coordinators. At the center of the visualization are smaller exhibitions and discoursive programs which mostly took place at the Nova Gallery. One visually distinctive event was the exhibition serie START SOLO that took place in 2003 and 2004. The exhibitions were a continuation of the 2002 exhibition Start, with the aim of introducing and presenting the work of young Croatian contemporary artists, in addition to stimulating productions of new work. The visualization also offers an insight into WHW's programs' dynamics, which can be observed through the participation of artists, curators, and theoreticians in the secondary events surrounding the early exhibitions (colored differently than the direct participation in the exhibit). From 2003, this can be observed through a growing num ber of smaller exhibitions and discoursive formats that mark a shift from the more conventional exhibition-focused programs toward creating a gallery that serves as a public space for communication and dis cussion.

Although the majority of participants in larger exhibition events only made a single relation within the program, ${ }^{360}$ the visualization also demonstrates that number of program participants realize multiple relations. This was predominantly the case with local actors who, alongside WHW members, stand out in the number of established relations; specifically, Mladen Stilinović and Sanja Iveković with 11 and 9 relations respectively, followed by Andreja Kulunčić and Vlado Martek with 6 relations,

360 The visualization would probably look different if the WHW collaborative network was analyzed to date, and would likely show some of the participants having more than one relation. 
Tomislav Gotovac, Ana Hušman, and David Maljković with 5 relations, as well as Igor Grubić, Goran Trbuljak, Stephen Wright, Marko Tadić, and Aleksandar Battista Ilić with 4 established relations.

Given that only the formal types of interaction and collaboration through the realization of programs were taken into account when generating the visualization, the assumed existence of strong ties within the network can only be distilled from the frequency of collaborations, while the qualitative research results, together with the research on the WHW program after 2006 mostly confirms the above listed actors a having strong ties with the collective. These ties presuppose the existence of long-term collaborations and an intertwining of professional and personal relations, but also express the aesthetical and ideological affinities of WHW members that are congenerous to the practices of certain artists (establishing the continuity of critical art practices from the socialist era, focusing on art practice as a social practice, contemplating new technologies as well as new forms of expression)

The visualization also confirms earlier claims that after 2000, the roles of the most central actors in the independent scene were no longer occupied by individuals, but rather by NGOs. For example, while the Multimedia Institute realizes 19 relations in the network, or Art Workshop Lazareti 16 relations, the important actors within these institutions who presumably participated in the program organization, such as Slaven Tolj, Tomislav Medak, or Marcell Mars, do not take central stage in the visualization. Such a representation is reflective of collective work within NGOs; the sharing of obligations and merits, and devising program concepts through joint participation and discussion. Consequently, the visualization allows for the synchronous assessment of all established collaborative relations in the first six programs took place in this period, it is important to note that the collaborative network of WHW never actually resembled Fig. 1 and Fig. 2, but was rather in a constant state of flux: some actors were recurring, some performed multiple roles, many were part of the network only at one point, while others were establishing different kinds of relations with the members of the collective outside of their official program. ${ }^{361}$ However, when talking about successful collaborations between individul actors and the WHW collective, it can be assumed that, if the need arises, these individual relations can be reactivated with WHW serving as a link among the actors within its existing network.

\section{CONCLUSION}

The structure of the Croatian cultural and art scene in 1990s can thus be described as a fragmented field of activities informally organized around smaller social circles. Such structural characteristics can be seen as a direct consequence of a transitional socio-political context and the unfavorable position of the cultural field at large. Consequently, it is not surprising that the end of 1990s through to the early 2000s was marked by an absence of central actors that would serve as network 'concentrators', even though there were prior instances of actors paving the way for the structural formation of the independent scene. Additionally, given the interview analysis, it can be concluded that despite fragmentation, the scene's structure was marked by a fair-

361 Given that the visualizations represent the researchers' construction based on the available documentation, the anal ysis did not employ standard calculations of network density and measurements of centrality.

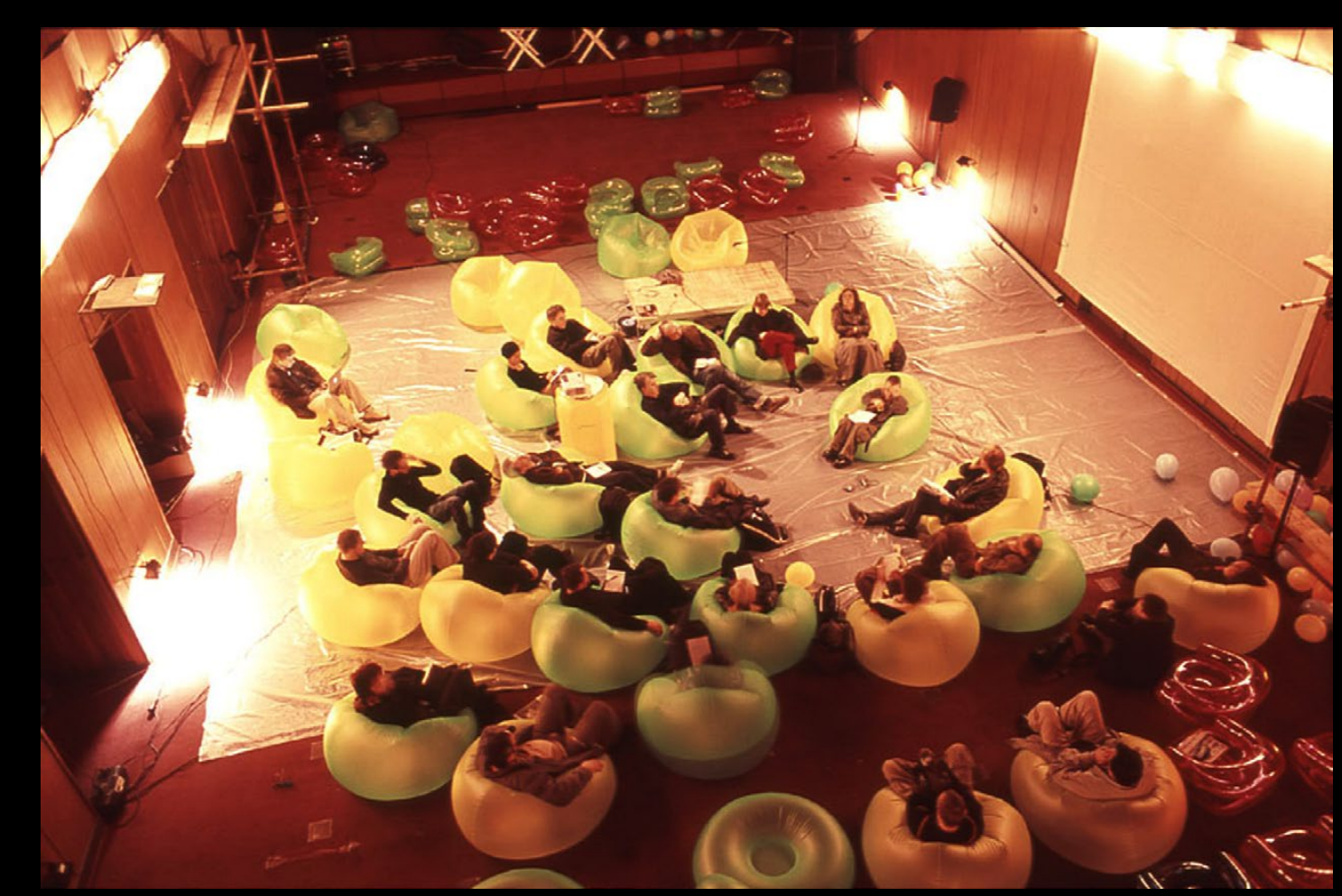

III. 5

Group Dynamics Symposium, May 6-9, 2004. Organized by the Zagreb - European Cultural Kapital 3000 platform. Courtesy of the WHW curatorial collective. 
ly high density of relations among actors. Therefore, the structural holes-or what Pachucki and Breiger describe as cultural holes ${ }^{362}$ - are not considered a primary characteristic of the structure of the independent and cultural scene of the 1990s. Conversely, the existence of such holes is evident when considering the relations between the dominant cultural matrix on one hand, and independent and progressive initiatives on the other.

Due to an absence of systemic institutional support for progressive art currents that existed in past decades, as well as hindered institutional inclusion of the younger generations, the 1990s can be viewed as a period of searching and regrouping, wherein the support of mid-generation protagonists played an important role. This resulted in the post-2000 formation of an almost para-institutional structure of the independent scene. In this structure, the newly-formed NGOs and platforms acted as both the structure and the main actors of the scene. The socio-political and cultural context was also echoed in the processes of forming relations within the network. These relations were primarily formed on the basis of shared ideological and aesthetical affinities of the actors-built on mechanisms of status and value-based homophily and transitivity, resulting in the proliferation of strong ties and a high density of the network. Even though the formation of relations between institutions and independent initiatives was challenging, they did in fact exist, and, unlike the independent scene, the activities of the institutions were perceived through the actions of individual institutional workers.

362 Mark A. Pachucki, and Ronald L.

Breiger, "Cultural holes: Beyond relationality in social networks and cultures," Annual Review of Sociology 36 (2010):
, the curatorial collective WHW an example of a typical network oncentrator in the independent scene, acting simultaneously as a collective identity and a NGO. According to the conducted qualitative study, WHW is one of the key actors on the cene, whose practice is perceived through the critique of socio-political and cultural climate of the 90s-viewing contemporary art practices as a part of wider social processes. Through the organization of various types of activities, WHW acts as a mediator between various NGOs on the local and national level, and various types of actors on the national and trans-national level, as well as between the older, mid, and younger generations of artists (contributing to the re-establishment of continuity with progressive art currents from the socialist era).

In conclusion, the independent scene's structure, the formation of its key actors, and the means of establishing relations within the network, were significantly defined by the socio-political and cultural context of the 1990s. It was precisely this context-perceived through the collapse of the socialist state, the growth of conservatism and nationalism, and a lack of infrastructure for contemporary art practices - that caused the efforts to create conditions for contemporary art production to be perceived as a form of collective resistance to the dominant social and cultural climate, or the struggle for context and self-positioning within the social and cultural field. In other words, it was precisely this struggle for structure that influenced the grouping of actors with similar ideological and aesthetical affinities, helping them form their communal story. 
ŽELJKA TONKOVIĆ, SANJA SEKELJ

Duality of Structure and Culture: A Network

Perspective on the Independent Cultural

Scene in Zagreb and the Formation of the WHW Curatorial Collective

pp. 166-192

Charmaz, Kathy. Constructing Grounded Theory: A Practical Guide through Qualitative Analysis. LondonThousand Oaks-New Delhi: Sage Publications, 2006.

Cvjetičanin, Biserka, and Vjeran Katunarić, eds. Kulturna politika Republike Hrvatske: nacionalni izvještaj. Zagreb: Ministarstvo kulture Republike Hrvatske - Institut za međunarodne odnose, 1998.

Herz, Andreas, Peters, Luisa, and Inga Truschkat. "How to do qualitative structural analysis: the qualitative interpretation of network maps and narrative interviews." Forum: Qualitative Social Researc (2015).
interviews. Forum: Qualitative Social Research 16/1

Janković, Vesna, and Nikola Mokrović, eds. Antiratna kampanja 1991. - 2011. Neispričana povijest. Zagreb: Documenta - Centar za suočavanje s prošlošću Antiratna kampanja, 2011.

Kadushin, Charles. Understanding Social Networks. epts and Findings. New York: Oxfor University Press, 2012

Knoke, David, and Song Yang. Social Network Analysis. Thousand Oaks: Sage, 2008 [1982].

Medak, Tomislav, and Petar Milat, eds. Prospects of Arkzin / Izgledi Arkzina. Zagreb: Arkzin - Multimedijalni institut, 2013.

Mische, Ann. "Cross-talk in movements: rethinking the culture-network link." In Social Movements and Networks: Relational Approaches to Collective Action, edited by Mario Diani and Doug McAdam, 258-280. New York: Oxford University Press, 2003.

Mische, Ann. "Relational sociology, culture, and agenMische, In The SAGE Handbook of Social Network Analysis, edited by John Scott and Peter J. Carrington, 80-97. Los Angeles-London: Sage, 2011.

Naša priča: 15 godina ATTACK!-a. Zagreb: Autonomni kulturni centar, 2013.

Pachucki, Mark A., and Ronald L. Breiger. "Cultural holes: Beyond relationality in social networks and culture." Annual Review of Sociology 36 (2010): 205-224.
Pejović, Katarina. "Bakal, Boris: navigator izmještanja i diskontinuiteta - portret multimedijalnog umjetnika." Up \& Underground 7/8 (2004): 18-33.

Stubbs, Paul. "Networks, Organisations, Movements Narratives and Shapes of Three Waves of Activism in Croatia." Polemos 15 (2012): 11-32.

Vidović, Dea. “Nezavisna kultura u Hrvatskoj (1990. 2010.)." In Dizajn i nezavisna kultura, edited by Maroje Mrduljaš and Dea Vidović, 9-39. Zagreb: Savez udruga Klubtura - UPI 2M PLUS d.o.o. - KURZIV, 2010.

Vidović, Dea. "Taktičke prakse u pristupima lokalnim kulturnim politikama u Zagrebu." Život umjetnosti 86 (2010): 22-35.

Wasserman, Stanley, and Katherine Faust. Socia Network Analysis. Methods and Applications. New York: Cambridge University Press, 2009.

White, Harrison C. Identity and Control: How Socia Formations Emerge. Princeton: Princeton University Press, 2008.

\section{ONLINE SOURCES}

Bauer, Una. "Crvene niti kontinuiteta i kolaboracije - intervju s kustoskim kolektivom WHW." Kulturpunkt, March 9, 2010. Accessed July 25, 2018. huturp kulturpunkt hr/content/crvene-niti-kontinuiteta-i-kolaboracije-0

Clubture. Accessed August 14, 2018. http://www.club ture.org/

Galerija ŠKUC, "Why MSE-projects?." Accessed October 4, 2018. http://www.galerijaskuc.si/v2/why-mseprojects/

Multimedijalni institut, "Zagreb - kulturni kapital Evrope 3000." Accessed August 14, 2018. www.mi2.hr/hr/suradnje/zagreb-kulturni-kapital-evrope-3000/

Sandić, Srđan. "Kritičar kao dionik, zagovarač i medijator - intervju s Markom Golubom." Vizkultura, March 9, 2016. Accessed July 25, 2018. https://vizkultura.hr/ kriticar-kao-dionik-zagovarac-i-medijator/

Spieker, Sven. "Interview with WHW Collective." ART Margins, July 5, 2011. Accessed July 25, 2018. http:// www.artmargins.com/index.php/5-interviews/635-interview-with-whw-collective-zagreb

Vidović, Dea. "Život s WHW-om - intervju s Dejanom Kršićem." Kulturpunkt, August 16, 2010. Accessed July 25, 2018. https://www.kulturpunkt.hr/content/\%C5\%BEivot-s-whw-om
WHW, "Što, kako i za koga, povodom 152. godišnjice Komunističkog manifesta." Accessed July 25, 2018. http://www.whw.hr/novosti/index.html

\section{UNPUBLISHED SOURCES}

Interview 1, interview by Ivana Meštrov and Željka Ton ković, November 3, 2015.

Interview 2, interview by Ivana Meštrov and Željka Tonković, November 24, 2015

Interview 4, interview by Ivana Meštrov and Željka Tonković, November 25, 2015

Interview 11, interview by Ivana Meštrov, December 22, 2015.

Interview 15, interview by Željka Tonković, March 17 2016.

Interview 16, interview by Sanja Horvatinčić and Željka Tonković, March 29, 2016.

Interview 17 , interview by Ivana Meštrov and Željka Tonković, March 29, 2016

Interview 18 , interview by Sanja Sekelj and Željka Tonković, December 6, 2016.

Interview 20, interview by Sanja Sekelj, December 8 2016.

Interview 21, interview by Sanja Sekelj and Željka Tonković, March 6, 2017.

Interview 25, interview by Sanja Sekelj and Željka Tonković, April 7, 2017. 